\title{
Model Hubungan antara Angka Korban Kecelakaan Lalu Lintas dan Faktor Penyebab Kecelakaan pada Jalan Tol Purbaleunyi
}

\author{
VIRLIA DIAN FRIDAYANTI, DWI PRASETYANTO
}

\author{
Jurusan Teknik Sipil, Institut Teknologi Nasional, Bandung \\ Email: virlia.dian@yahoo.co.id
}

\begin{abstract}
ABSTRAK
Kecelakaan lalu lintas merupakan hasil dari kombinasi faktor-faktor penyebab yang yang terdiri dari faktor manusia, kendaraan, jalan, dan lingkungan. Penelitian ini bertujuan untuk mengetahui variabel dominan dari beberapa faktor penyebab kecelakaan dengan memodelkan hubungan antara angka korban kecelakaan lalu lintas dengan variabel faktor penyebab kecelakaan di Jalan Tol Purbaleunyi pada tahun 2015-2017. Data yang digunakan pada penelitian ini berupa data sekunder yang terdiri dari data jumlah korban dan jumlah kecelakaan yang diakibatkan oleh faktor-faktor penyebab kecelakaan. Metode penelitian yang digunakan dalam penelitian ini adalah metode analisis regresi linear berganda dengan melakukan uji linearitas dan uji korelasi terlebih dahulu. Uji linearitas digunakan untuk memastikan apakah data yang akan dianalisis dapat menggunakan analisis regresi linear atau tidak, sedangkan uji korelasi digunakan untuk menentukan hubungan antara variabel baik antara sesama variabel bebas maupun antara variabel peubah bebas dengan variabel peubah tidak bebas. Berdasarkan hasil penelitian yang dilakukan pada tahun 2015-2017, variabel utama faktor kecelakaan diakibatkan oleh faktor manusia dan faktor kendaraan yaitu variabel mengantuk $\left(X_{3}\right)$ dan rem blong $\left(X_{9}\right)$.
\end{abstract}

Kata kunci: Kecelakaan lalu lintas, faktor penyebab kecelakaan lalu lintas, regresi linear berganda.

\begin{abstract}
Traffic accidents are the result of a combination of factors causes which consists of the human factor, vehicle, road, and environment. This study aims to determine the majority of the accidents variable of several factors that cause accidents by modeling the relationship between the numbers of traffic accident victims with variable factors causing the accident on Highway Purbaleunyi in 2015-2017. The data used in this study of secondary data consists of data on the number of victims and the number of accidents caused by factors that cause accidents. The method used in this research is multiple linear regression analysis to test the linearity and correlation test beforehand. Linearity test used to determine whether the data will be analyzed using linear regression analysis or not, whereas the correlation test was used to determine the relationship between both variables among the independent variables and the independent variables with the variable variable variable is not free. Based on the results of research conducted in 20152017, the main variable of the accident factor is caused by human factors and vehicle factors, which are variable drowsiness $\left(X_{3}\right)$ and brake failure $\left(X_{9}\right)$.
\end{abstract}

Keywords: Traffic accidents, the causes of traffic accidents, multiple linear regression. 


\section{PENDAHULUAN}

Volume lalu lintas yang semakin meningkat dari tahun ke tahun mengakibatkan semakin tingginya resiko kecelakaan lalu lintas di Jalan raya salah satunya pada Jalan Tol Purbaleunyi. Berdasarkan data yang didapatkan dari PT Jasa Marga cabang Purbaleunyi tahun 2018, volume kendaraan yang melintasi Jalan Tol Purbaleunyi meningkat di setiap tahunnya dan disertai jumlah kecelakaan di setiap tahunnya, sehingga perlu ditelusuri lebih lanjut terkait penyebab utama dari kecelakaan tersebut agar dapat dilakukan cara pencegahan kecelakaan akibat faktor-faktor tersebut sehingga dapat menurunkan jumlah kecelakaan di tahun-tahun berikutnya. Gambar 1 menunjukkan peta lokasi penelitian tugas akhir yang dilakukan di sepanjang Jalan Tol Purbaleunyi.

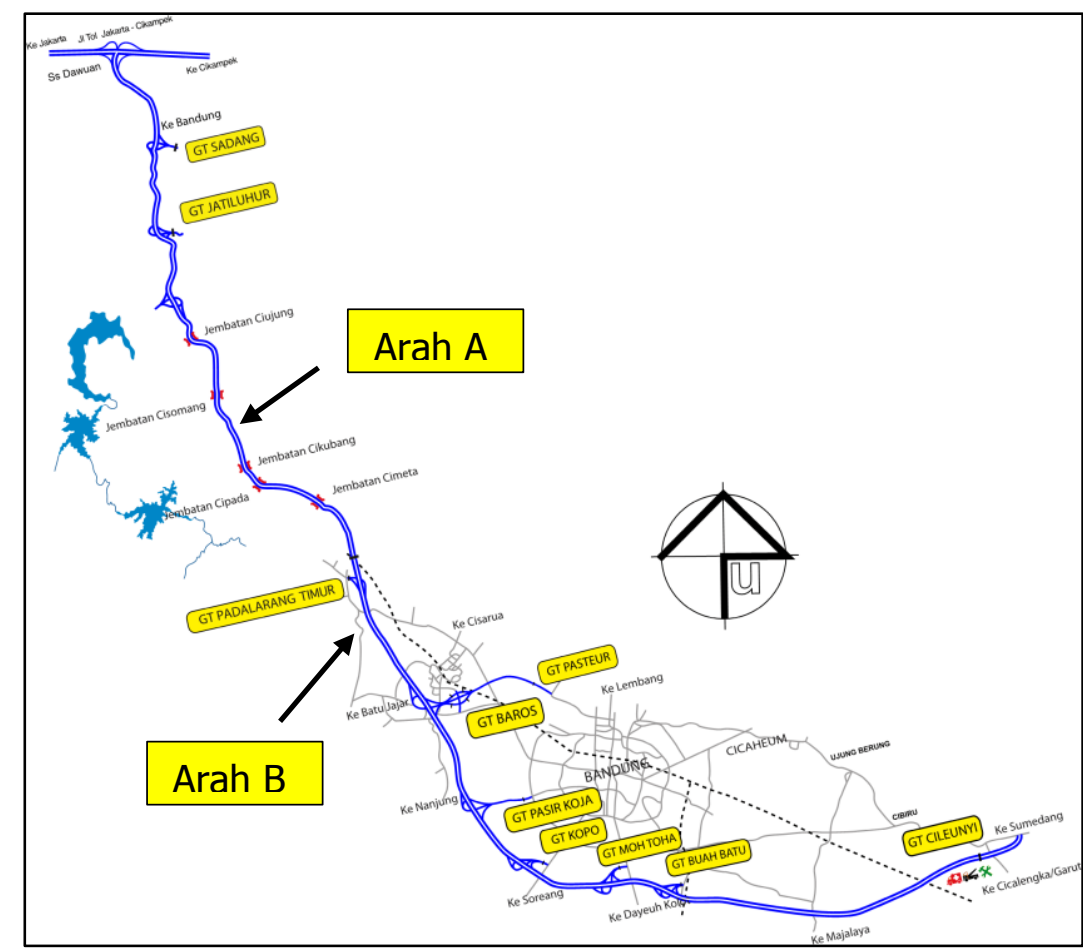

Gambar 1. Peta lokasi penelitian

(Sumber: PT Jasa Marga Cabang Purbaleunyi, 2018)

Faktor penyebab kecelakaan lalu lintas terbagi menjadi 4 faktor yaitu faktor manusia, kendaraan, jalan dan lingkungan yang diikuti oleh beberapa variabel dari setiap faktor tersebut. Menurut PT Jasa Marga banyaknya kecelakaan pada Tahun 2015-2017 sebagian besar diakibatkan oleh faktor manusia (pengemudi) dan kendaraan yaitu pada faktor manusia adalah sebesar 79,375\% pada tahun 2015, pada Tahun 2016 adalah sebesar $85,03 \%$, dan $80 \%$ pada Tahun 2017. Serta pada faktor kendaraan sebesar $20 \%$ pada Tahun 2015, pada tahun 2016 sebesar 14,97\% dan 19,23\% pada Tahun 2017. Dari jumlah kecelakaan tersebut mengakibatkan adanya korban kecelakaan berjumlah 324 orang pada tahun 2015, 182 orang pada tahun 2016, dan 265 orang pada tahun 2017. Banyaknya jumlah korban kecelakaan di Jalan Tol Purbaleunyi tersebut akan berakibat menurunnya kinerja ruas jalan tersebut, mengurangi kenyamanan dan juga keselamatan pengguna jalan lainnya.

Tujuan pada penelitian ini diharapkan dapat mengetahui variabel dari faktor penyebab kecelakaan yang paling berpengaruh terhadap jumlah korban kecelakaan lalu lintas pada Tol 
Purbaleunyi dengan cara memodelkan hubungan angka kecelakaan dengan faktor penyebab kecelakaan menggunakan metode regresi linear berganda.

\section{TINJAUAN PUSTAKA}

\subsection{Kecelakaan Lalu Lintas}

Kecelakaan lalu lintas adalah suatu peristiwa di Jalan yang tidak disangka-sangka dan tidak disengaja melibatkan kendaraan dengan atau tanpa pemakai Jalan lainnya, mengakibatkan korban manusia atau kerugian harta benda (Kementerian Hukum dan Hak Asasi Manusia, 2004). Definisi lain tentang kecelakaan lalu lintas adalah kejadian di mana sebuah kendaraan bermotor tabrakan dengan benda lain dan menyebabkan kerusakan. Kadang kecelakaan ini dapat mengakibatkan luka-luka atau kematian manusia atau binatang (World Health Organization, 2004).

\section{a. Jenis Kecelakaan Lalu Lintas}

Berdasarkan Kementerian Hukum dan Hak Asasi Manusia (2009) tentang Lalu Lintas dan Angkutan Jalan, bahwa jenis kecelakaan lalu lintas dibagi menjadi tiga bagian, yaitu:

1. Kecelakaan lalu lintas ringan.

2. Kecelakaan lalu lintas sedang.

3. Kecelakaan lalu lintas berat.

\section{b. Tingkat Keparahan Korban Kecelakaan}

Korban pada kecelakaan lalu lintas dibagi menjadi tiga bagian, yaitu (Kementerian Hukum dan Hak Asasi Manusia, 2009):

1. Luka ringan.

2. Luka berat.

3. Meninggal dunia.

\section{c. Faktor-faktor Penyebab Kecelakaan}

Berdasarkan Kementerian Hukum dan Hak Asasi Manusia (2009) tentang Lalu Lintas dan Angkutan Jalan, penyebab kecelakaan dibagi menjadi empat faktor, yaitu:

1. Manusia (pengemudi dan pemakai jalan lainnya).

2. Ketidaklayakan kendaraan.

3. Ketidaklayakan jalan.

4. Lingkungan (asap kendaraan, asap lingkungan, hewan, cuaca).

\subsection{Uji Statistik}

\section{Uji Linearitas}

Uji statistik ini perlu dilakukan untuk memastikan apakah model yang digunakan dapat dianalisis dengan model analisis regresi linear atau model analisis regresi tidak linear (Tamin, 2008). Hasil uji linearitas dapat disimpulkan dengan asumsi sebagai berikut:

a. Jika Nilai Deviation from Linearity Sig $\geq 0,05$ maka terdapat hubungan linear secara signifikan antara variabel peubah bebas dengan peubah tidak bebas.

b. Jika Nilai Deviation from Linearity Sig $\leq$ 0,05 maka tidak terdapat hubungan linear secara signifikan antara variabel peubah bebas dengan peubah tidak bebas.

\section{Uji Korelasi}

Uji statistik ini harus dilakukan untuk penentuan hubungan antara variabel, baik antara sesama variabel pubah bebas maupun antara variabel peubah bebas dengan variabel peubah tidak bebas. Sesama peubah bebas tidak boleh saling berkorelasi, sedangkan antara peubah tidak bebas dengan peubah bebas harus ada korelasi yang kuat (baik positif maupun 
negatif). Untuk mengetahui hasil tingkat hubungan antara peubah bebas dengan peubah tidak bebas, maka dapat dilihat pada pedoman interpretasi koefisien korelasi pada Tabel 1.

Tabel 1. Pedoman Interpretasi Koefisien Korelasi

\begin{tabular}{cc} 
Nilai & Tingkat Hubungan \\
\hline $0,00-0,199$ & Sangat Lemah \\
\hline $0,20-0,399$ & Lemah \\
\hline $0,40-0,599$ & Sedang \\
\hline $0,60-0,799$ & Kuat \\
\hline $0,80-1,00$ & Sangat Kuat \\
\hline
\end{tabular}

(Sumber: Sugiyono, 2014)

\section{Analisis Regresi Linear Berganda}

Regresi linear berganda adalah analisis regresi yang menjelaskan hubungan antara variabel peubah tidak bebas $(Y)$ dengan faktor-faktor yang mempengaruhi lebih dari satu variabel peubah bebas $(X)$. Tujuan analisis regresi linear berganda ini adalah untuk memprediksi nilai $Y$ dari nilai $X$ tersebut. Analisis ini digunakan untuk mengetahui hubungan antara dua atau lebih variabel peubah bebas terhadap variabel peubah tidak bebas secara serentak atau bersamaan dan juga secara individual. Dari hasil analisis ini juga dapat mengetahui Koefisien yang menunjukkan seberapa besar hubungan yang terjadi antara variabel peubah bebas secara serentak atau bersama-sama terhadap variabel peubah tidak bebas. Menurut Tamin (2008) bentuk umum metode analisis regresi linear berganda seperti pada Persamaan 1.

$$
Y=a+b_{1} X_{1}+b_{2} X_{2}+\cdots+b_{Z} X_{Z}
$$

halmana:

$Y \quad=$ peubah tidak bebas,

$X_{1} \ldots X_{Z}=$ peubah bebas,

a $\quad=$ konstanta,

$b_{1} \ldots b_{z}=$ koefisien regresi.

\subsection{Studi Terdahulu}

Penelitian ini diawali dengan pengumpulan bahan-bahan studi terdahulu yang sudah dilakukan oleh peneliti sebelumnya untuk membantu mencapai tujuan penulisan seperti yang ditunjukkan pada Tabel 2.

\section{METODE PENELITIAN}

1. Identifikasi Masalah dan Penentuan Topik Penelitian

Studi ini diawali dengan pengamatan terhadap angka kecelakaan lalu lintas di jalan tol khususnya di jalan tol Purbaleunyi yang terus terjadi kecelakaan dan menghasilkan korban dari kecelakaan tersebut di setiap tahunnya, sehingga membutuhkan penanganan guna mengurangi tingkat kecelakaan yang terjadi. Maka untuk mengetahui faktor utama dari penyebab kecelakaan tersebut, dibuat model hubungan antara angka kecelakaan lalu lintas dengan faktor penyebab kecelakaan.

2. Tinjauan Pustaka Penelitian

Penyusunan tugas akhir ini diawali dengan pengumpulan bahan-bahan studi pustaka sebagai referensi untuk membantu mencapai tujuan penulisan. Referensi tugas akhir yang digunakan dari beberapa sumber yang berasal dari jurnal, buku, serta internet mengenai pembahasan yang sesuai dengan topik tugas akhir. Tinjauan pustaka ini bertujuan untuk memperoleh metode serta teori-teori sebagai acuan penelitian. 
Tabel 2. Studi Terdahulu

\begin{tabular}{|c|c|c|c|c|}
\hline No. & $\begin{array}{l}\text { Nama, } \\
\text { Tahun }\end{array}$ & Judul & Bentuk Tulisan & Hasil Penelitian \\
\hline 1. & $\begin{array}{l}\text { Lestari } \\
(2018)\end{array}$ & $\begin{array}{l}\text { Kajian Mata Rantai } \\
\text { Keselamatan Lalu } \\
\text { Lintas di Jalan Tol } \\
\text { Purbaleunyi }\end{array}$ & $\begin{array}{l}\text { - Metode } \\
\text { perbandingan } \\
\text { eksposur, } \\
\text { risiko, dan } \\
\text { konsekuensi } \\
\text { kecelakaan } \\
\text { - Mata rantai } \\
\text { keselamatan } \\
\text { lalu lintas }\end{array}$ & $\begin{array}{l}\text { Pendekatan yang digunakan pada penelitian ini } \\
\text { adalah berupa pendekatan satu dimensi yang } \\
\text { menampilkan frekuensi jenis kecelakaan dan korban } \\
\text { kecelakaan lalu lintas, pendekatan dua dimensi yang } \\
\text { menampilkan risiko kecelakaan lalu lintas, dan } \\
\text { pendekatan tiga dimensi yang menampilkan } \\
\text { eksposur, risiko, dan konsekuensi kecelakaan. } \\
\text { Kemudian konsep dari tiga dimensi dapat diperluas } \\
\text { untuk melihat rasio mata rantai atau dimensi dimana } \\
\text { numerator pada perbandingan yang terakhir } \\
\text { berhubungan dengan gambaran situasi keselamatan. }\end{array}$ \\
\hline 2. & $\begin{array}{l}\text { Adelaide } \\
(2012)\end{array}$ & $\begin{array}{l}\text { Gambaran Faktor- } \\
\text { Faktor Penyebab } \\
\text { Kecelakaan Lalu } \\
\text { Lintas di Jalan Tol } \\
\text { Purbaleunyi Tahun } \\
\text { 2010-2011 }\end{array}$ & $\begin{array}{l}\text { - Pendekatan } \\
\text { cross-sectional }\end{array}$ & $\begin{array}{l}\text { Desain penelitian yang digunakan dalam penelitian } \\
\text { ini adalah penelitian kuantitatif bersifat deskriptif } \\
\text { dengan pendekatan cross-sectional yang bertujuan } \\
\text { untuk mengetahui gambaran faktor-faktor penyebab } \\
\text { kejadian kecelakaan lalu lintas di Jalan Tol } \\
\text { Purbaleunyi Tahun 2010-2011 agar dapat } \\
\text { mengetahui faktor manakah yang menjadi faktor } \\
\text { utama dari penyebab kecelakaan lalu lintas di Jalan } \\
\text { Tol Purbaleunyi Tahun 2010-2011. }\end{array}$ \\
\hline 3. & $\begin{array}{l}\text { Perdana } \\
\text { (2018) }\end{array}$ & $\begin{array}{l}\text { Relavansi Teori } \\
\text { Perilaku Terencana } \\
\text { Pada Niat Konsumen } \\
\text { Pengguna Bus Trans } \\
\text { Metro Bandung }\end{array}$ & $\begin{array}{l}\text { - Metode regresi } \\
\text { linear berganda }\end{array}$ & $\begin{array}{l}\text { Berdasarkan hasil dari penelitian ini adalah bahwa } \\
\text { variabel peubah bebas yaitu sikap }\left(X_{1}\right) \text {, norma } \\
\text { subyektif }\left(X_{2}\right) \text {, dan kontrol perilaku }\left(X_{3}\right) \text { tidak } \\
\text { terdapat pengaruh yang signifikan terhadap variabel } \\
\text { peubah tidak bebas yaitu niat perilaku }(Y) \text { tetapi } \\
\text { peubah bebas } X_{1}, X_{2} \text { dan } X_{3} \text { memiliki pengaruh } \\
\text { secara simultan atau bersama - sama terhadap } \\
\text { peubah tidak bebas }(Y) \text {. }\end{array}$ \\
\hline
\end{tabular}

\section{Pengumpulan Data}

Pada tahap ini dilakukan pengumpulan data berupa data sekunder. Data sekunder yang digunakan merupakan data yang diperoleh dari laporan atau dokumen yang terkait dengan masalah yang diteliti. Data berasal dari kejadian kecelakaan lalu lintas (jumlah kecelakaan, jumlah korban, dan penyebab kecelakaan selama tiga tahun terakhir dari tahun 2015 sampai tahun 2017) yang didapatkan dari PT Jasa Marga Cabang Purbaleunyi.

5. Uji Korelasi dan Uji Linearitas

Uji korelasi digunakan untuk menentukan hubungan antara variabel baik antara sesama variabel peubah bebas maupun antara variabel peubah bebas dengan variabel peubah tidak bebas. Sedangkan uji linearitas digunakan untuk memastikan apakah model yang akan dianalisis dapat menggunakan analisis regresi linear.

6. Analisis Metode Regresi Linear Berganda

Pada penelitian ini digunakan 13 (tiga belas) variabel peubah bebas $(X)$ yang yang dapat dilihat pada Tabel 3 dan angka korban kecelakaan sebagai variabel peubah tidak bebas $(Y)$ yang dihitung dengan dengan metode regresi linear berganda.

Tabel 3. Variabel Peubah Bebas

\begin{tabular}{cccc}
\hline Variabel Bebas & Keterangan & Variabel Bebas & Keterangan \\
\hline $\boldsymbol{X}_{\mathbf{1}}$ & Kurang Antisipasi & $\boldsymbol{X}_{\mathbf{7}}$ & Ban Pecah \\
\hline $\boldsymbol{X}_{\mathbf{2}}$ & Lengah & $\boldsymbol{X}_{\mathbf{8}}$ & Slip \\
\hline $\boldsymbol{X}_{\mathbf{3}}$ & Mengantuk & $\boldsymbol{X}_{\mathbf{9}}$ & Rem Blong \\
\hline $\boldsymbol{X}_{\mathbf{4}}$ & Mabuk & $\boldsymbol{X}_{\mathbf{1 0}}$ & Kerusakan Mesin \\
\hline $\boldsymbol{X}_{\mathbf{5}}$ & Tidak Tertib & $\boldsymbol{X}_{\mathbf{1 1}}$ & Kerusakan Mekanis \\
\hline $\boldsymbol{X}_{\mathbf{6}}$ & Lain - Lain Dalam Pengemudi & $\boldsymbol{X}_{\mathbf{1 2}}$ & Kendaraan Berhenti \\
\hline & & $\boldsymbol{X}_{\mathbf{1 3}}$ & Lain - Lain Dalam Kendaraan \\
\hline
\end{tabular}

(Sumber: PT Jasa Marga Cabang Purbaleunyi, 2018) 


\section{ANALISIS DAN PEMBAHASAN}

\subsection{Data Kecelakaan}

Tabel 4 memperlihatkan data kecelakaan dan korban lalu lintas di Jalan Tol Purbaleunyi pada kedua arah yaitu pada arah menuju Cileunyi (Arah A) dan arah menuju Purwakarta (Arah B) seperti pada Gambar 1.

Tabel 4. Data Kecelakaan dan Korban Lalu Lintas Jalan tol Purbaleunyi

\begin{tabular}{|c|c|c|c|c|c|c|c|c|c|c|c|c|c|c|}
\hline \multirow{3}{*}{$\begin{array}{l}\text { TAHUN } \\
\text { arah }\end{array}$} & \multicolumn{6}{|c|}{ Kecelakaan } & \multirow{3}{*}{ TOTAL } & \multicolumn{6}{|c|}{ Korban } & \multirow{3}{*}{ TOTAL } \\
\hline & \multicolumn{2}{|c|}{ Ringan } & \multicolumn{2}{|c|}{ Sedang } & \multicolumn{2}{|c|}{ Berat } & & \multicolumn{2}{|c|}{$\begin{array}{c}\text { Luka } \\
\text { Ringan }\end{array}$} & \multicolumn{2}{|c|}{$\begin{array}{l}\text { Luka } \\
\text { Berat }\end{array}$} & \multicolumn{2}{|c|}{$\begin{array}{c}\text { Meninggal } \\
\text { Dunia }\end{array}$} & \\
\hline & A & B & A & B & A & B & & A & B & $\mathbf{A}$ & B & A & B & \\
\hline 2015 & 22 & 38 & 62 & 48 & 138 & 78 & 386 & 99 & 85 & 49 & 58 & 7 & 12 & 310 \\
\hline 2016 & 59 & 75 & 52 & 46 & 72 & 81 & 385 & 43 & 47 & 35 & 36 & 3 & 7 & 171 \\
\hline 2017 & 30 & 46 & 76 & 40 & 39 & 30 & 261 & 57 & 59 & 69 & 33 & 24 & 15 & 257 \\
\hline
\end{tabular}

A : Arah menuju Cileunyi

B : Arah menuju Purwakarta

(Sumber: PT Jasa Marga Cabang Purbaleunyi, 2018)

\subsection{Hasil Uji Linearitas}

Uji linearitas dilakukan untuk memastikan model yang digunakan dapat dianalisis dengan model analisis regresi linear atau tidak. Hasil yang didapatkan dari uji linearitas dapat dilihat pada Tabel 5. Berdasarkan Tabel 5 hasil uji linearitas data kumulatif tahun 2015-2017 menunjukkan bahwa nilai signifikan Deviation from Linearity yang didapatkan bahwa variabel peubah bebas $\boldsymbol{X}_{\mathbf{3}}, \boldsymbol{X}_{\mathbf{6}}, \boldsymbol{X}_{\mathbf{7}}, \boldsymbol{X}_{\mathbf{8}}, \boldsymbol{X}_{\mathbf{9}}$ dan $\boldsymbol{X}_{\mathbf{1 1}}$ adalah $\geq 0,05$ yang berarti peubah bebas tersebut memiliki hubungan yang linear dengan peubah tidak bebas $Y$.

Tabel 5. Uji Linearitas pada Variabel $Y$ \& $X$ Kumulatif pada Tahun 2015-2017

\begin{tabular}{ccc}
\hline $\begin{array}{c}\text { Hubungan } \\
\text { Variabel } \mathbf{Y} \\
\text { dengan }\end{array}$ & $\begin{array}{c}\text { Sig. } \\
\text { Deviation } \\
\text { From } \\
\text { Linearity }\end{array}$ & Keterangan \\
\hline $\boldsymbol{X}_{\mathbf{1}}$ & 0,000 & Tidak Linear \\
\hline $\boldsymbol{X}_{\mathbf{2}}$ & 0,000 & Tidak Linear \\
\hline $\boldsymbol{X}_{\mathbf{3}}$ & 0,505 & Linear \\
\hline $\boldsymbol{X}_{\mathbf{4}}$ & 0,000 & Tidak Linear \\
\hline $\boldsymbol{X}_{\mathbf{6}}$ & 0,360 & Linear \\
\hline $\boldsymbol{X}_{\mathbf{7}}$ & 0,590 & Linear \\
\hline $\boldsymbol{X}_{\mathbf{8}}$ & 0,414 & Linear \\
\hline $\boldsymbol{X}_{\mathbf{9}}$ & 0,451 & Linear \\
\hline $\boldsymbol{X}_{\mathbf{1 0}}$ & 0,000 & Tidak Linear \\
\hline $\boldsymbol{X}_{\mathbf{1 1}}$ & 0,359 & Linear \\
\hline $\boldsymbol{X}_{\mathbf{1 2}}$ & 0,000 & Tidak Linear \\
\hline
\end{tabular}

\subsection{Hasil Uji Korelasi}

Uji korelasi dilakukan dengan cara menentukan terlebih dahulu variabel peubah bebas dan variabel peubah tidak bebas yang akan di uji. Uji korelasi dilakukan untuk mengetahui tingkat hubungan antara sesama variabel peubah bebas $(X)$ maupun antara variabel peubah bebas $(X)$ dan peubah tidak bebasnya $(Y)$. Hasil yang didapatkan dari uji korelasi dapat dilihat pada Tabel 6 . Berdasarkan Tabel 6 yaitu hasil uji korelasi faktor penyebab dan angka korban kumulatif tahun 2015-2017 menunjukkan bahwa ada hubungan antara 
variabel peubah bebas yang memiliki hubungan yang kuat yaitu hubungan antara variabel $X_{3}$ dengan $X_{7}$ yaitu sebesar 0,683.

Tabel 6. Nilai Korelasi Variabel $Y \& X$ Kumulatif Tahun 2015-2017

\begin{tabular}{|c|c|c|c|c|c|c|c|c|}
\hline & & $Y$ & $X_{3}$ & $X_{6}$ & $X_{7}$ & $X_{8}$ & $X_{9}$ & $X_{11}$ \\
\hline \multirow{7}{*}{$\begin{array}{c}\text { Pearson } \\
\text { Correlation }\end{array}$} & $Y$ & 1,000 & & & & & & \\
\hline & $X_{3}$ & 0,872 & 1,000 & & & & & \\
\hline & $X_{6}$ & 0,129 & 0,300 & 1,000 & & & & \\
\hline & $X_{7}$ & 0,578 & 0,683 & $-0,068$ & 1,000 & & & \\
\hline & $X_{8}$ & 0,420 & 0,245 & $-0,135$ & $-0,101$ & 1,000 & & \\
\hline & $X_{9}$ & 0,517 & 0,257 & $-0,090$ & $-0,159$ & 0,594 & 1,000 & \\
\hline & $X_{11}$ & 0,301 & 0,272 & $-0,374$ & 0,551 & 0,428 & 0,073 & 1,000 \\
\hline
\end{tabular}

\subsection{Analisis Regresi Linear Berganda}

Analisis regresi linear berganda dilakukan dengan tahap demi tahap sampai hanya tersisa satu variabel saja dengan cara menentukan variabel/parameter yang mempunyai korelasi terkecil terhadap variabel peubah tidak bebas nya dan hilangkan parameter tersebut kemudian lakukan kembali analisis regresi linear berganda satu demi satu sampai hanya tertinggal satu variabel/parameter saja. Hasil yang didapatkan dari analisis regresi linear berganda dapat dilihat pada Tabel 7 sedangkan hasil uji $t$ dapat dilihat pada Tabel 8 . Berdasarkan hasil analisis regresi linear berganda kumulatif tahun 2015-2017 yang dapat dilihat pada Tabel 7 menunjukkan bahwa variabel yang memenuhi kriteria tanda yang diharapkan adalah pada model tahap 4 dan model tahap 5, tetapi jumlah variabel yang ada pada model tahap 4 lebih banyak dibandingkan jumlah variabel pada model tahap 5 . Selain itu, $R^{2}$ pada model tahap 4 lebih besar dibandingkan dengan $R^{2}$ pada model tahap 5 , dan juga model pada tahap 4 menunjukkan $F_{\text {hitung }}>F_{\text {tabel }}$ atau Signifikasi ( $\mathrm{sig}$ ) $<0,05$ yang artinya terdapat pengaruh variabel peubah bebas $X$ secara simultan atau bersama-sama terhadap variabel peubah tidak bebas $Y$ maka dari itu dipilihlah model pada tahap 4 . Sedangkan berdasarkan hasil uji $t$ kumulatif tahun 2015-2017 yang dapat dilihat pada Tabel 8 menunjukkan bahwa variabel peubah bebas yang memiliki pengatruh terhadap variabel peubah tidak bebasnya adalah variabel mengantuk $\left(X_{3}\right)$ dan variabel rem blong $\left(X_{9}\right)$. Dari hal tersebut didapatkan rumus regresi linear berganda seperti pada Persamaan 1. Persamaan yang didapatkan dari analisis regresi linear berganda pada tahun kumulatif ini dapat disimpulkan bahwa dari tahun 2015-2017 penyebab kecelakaan yang paling berpengaruh terhadap jumlah korban kecelakaan adalah faktor pengemudi yang mengantuk $\left(X_{3}\right)$ dan kendaraan yang mengalami rem blong $\left(X_{9}\right)$.

Tabel 7. Hasil Pemodelan Hubungan Antara Angka Korban dan Penyebab Kecelakaan Kumulatif pada Tahun 2015-2017

\begin{tabular}{|c|c|c|c|c|c|c|c|c|}
\hline \multirow{2}{*}{ No } & \multirow{2}{*}{ Peubah } & \multirow{2}{*}{$\begin{array}{l}\text { Tanda Yang } \\
\text { Diharapkan }\end{array}$} & \multirow{2}{*}{$\begin{array}{c}\text { Parameter } \\
\text { Model }\end{array}$} & \multicolumn{5}{|c|}{ Tahap } \\
\hline & & & & 1 & 2 & 3 & 4 & 5 \\
\hline 1 & intersep & $+/-$ & $c$ & $-6,891$ & $-6,713$ & $-6,861$ & $-6,813$ & $-5,464$ \\
\hline 2 & mengantuk & + & $X_{3}$ & 3,862 & 3,742 & 3,905 & 3,892 & 4,288 \\
\hline 3 & $\begin{array}{l}\text { Lain-lain } \\
\text { manusia }\end{array}$ & + & $X_{6}$ & $-2,262$ & - & - & - & - \\
\hline 5 & Slip & + & $X_{8}$ & $-7,543$ & $-8,394$ & $-2,537$ & - & - \\
\hline 6 & Rem blong & + & $X_{9}$ & 8,185 & 8,637 & 6,609 & 5,726 & - \\
\hline 7 & $\begin{array}{c}\text { kerusakan } \\
\text { mekanis }\end{array}$ & + & $X_{11}$ & 6,502 & 8,307 & - & - & - \\
\hline \multicolumn{4}{|c|}{$R^{2}$} & 0,868 & 0,867 & 0,855 & 0,853 & 0,761 \\
\hline \multicolumn{4}{|c|}{$F-s t a t$} & 5,277 & 8,142 & 11,748 & 20,330 & 25,494 \\
\hline \multicolumn{4}{|c|}{$F-t a b e l$} & 5,190 & 4,760 & 4,740 & 5,320 & \\
\hline
\end{tabular}


Model yang didapatkan sebagai berikut.

$$
Y=-6,813+3,892 X_{3}+5,726 X_{9}
$$

Tabel 8. Hasil Uji $t$ Kumulatif pada Tahun 2015-2017

\begin{tabular}{|c|c|c|c|c|c|c|}
\hline Tahap & Peubah & $\begin{array}{c}\text { Parameter } \\
\text { Model }\end{array}$ & $t_{\text {hitung }}$ & $t_{t a b e l}$ & Signifikansi & Keterangan \\
\hline \multirow{5}{*}{1} & Mengantuk & $X_{3}$ & 3,446 & \multirow{5}{*}{2,132} & 0,026 & Berpengaruh \\
\hline & $\begin{array}{l}\text { Lain-Lain } \\
\text { Manusia }\end{array}$ & $x_{6}$ & $-0,210$ & & 0,844 & $\begin{array}{c}\text { Tidak } \\
\text { Berpengaruh }\end{array}$ \\
\hline & Slip & $X_{8}$ & $-0,469$ & & 0,663 & $\begin{array}{c}\text { Tidak } \\
\text { Berpengaruh }\end{array}$ \\
\hline & Rem Blong & $X_{9}$ & 1,212 & & 0,292 & $\begin{array}{c}\text { Tidak } \\
\text { Berpengaruh }\end{array}$ \\
\hline & $\begin{array}{l}\text { Kerusakan } \\
\text { Mekanis }\end{array}$ & $X_{11}$ & 0,405 & & 0,706 & $\begin{array}{c}\text { Tidak } \\
\text { Berpengaruh }\end{array}$ \\
\hline \multirow{4}{*}{2} & Mengantuk & $X_{3}$ & 4,322 & \multirow{4}{*}{2,015} & 0,008 & Berpengaruh \\
\hline & Slip & $X_{8}$ & $-0,600$ & & 0,575 & $\begin{array}{c}\text { Tidak } \\
\text { Berpengaruh }\end{array}$ \\
\hline & Rem Blong & $X_{9}$ & 1,501 & & 0,194 & $\begin{array}{c}\text { Tidak } \\
\text { Berpengaruh }\end{array}$ \\
\hline & $\begin{array}{l}\text { Kerusakan } \\
\text { Mekanis }\end{array}$ & $X_{11}$ & 0,682 & & 0,526 & $\begin{array}{c}\text { Tidak } \\
\text { Berpengaruh }\end{array}$ \\
\hline \multirow{3}{*}{3} & Mengantuk & $X_{3}$ & 4,920 & \multirow{3}{*}{1,943} & 0,003 & Berpengaruh \\
\hline & Slip & $X_{8}$ & $-0,241$ & & 0,818 & $\begin{array}{c}\text { Tidak } \\
\text { Berpengaruh }\end{array}$ \\
\hline & Rem Blong & $X_{9}$ & 1,406 & & 0,209 & $\begin{array}{c}\text { Tidak } \\
\text { Berpengaruh }\end{array}$ \\
\hline \multirow{2}{*}{4} & Mengantuk & $X_{3}$ & 5,284 & \multirow{2}{*}{1,895} & 0,001 & Berpengaruh \\
\hline & Rem Blong & $X_{9}$ & 2,094 & & 0,047 & Berpengaruh \\
\hline 5 & Mengantuk & $X_{3}$ & 5,049 & 1,859 & 0,001 & Berpengaruh \\
\hline
\end{tabular}

\section{KESIMPULAN}

1. Variabel dominan dari faktor penyebab kecelakaan lalu lintas di Jalan Tol Purbaleunyi pada Tahun 2015-2017 yaitu adalah dari faktor pengemudi yaitu kurang antisipasi dan mengantuk sedangkan dari faktor kendaraan yaitu ban pecah dan rem blong.

2. Variabel dominan dari faktor penyebab kecelakaan lalu lintas di Jalan Tol Purbaleunyi berdasarkan data kumulatif pada Tahun 2015-2017 menunjukkan bahwa yang memiliki pengaruh besar terhadap adanya korban kecelakaan adalah faktor penyebab kecelakaan akibat mengantuk dan rem blong

3. Pemodelan hubungan antara angka korban kecelakaan dengan faktor penyebab kecelakaan lalu lintas yang diambil adalah hasil pemodelan kumulatif pada Tahun 20152017 yang membentuk persamaan dari variabel peubah bebas yaitu mengantuk $\left(X_{3}\right)$ dan rem blong $\left(X_{9}\right)$. 


\section{DAFTAR RUJUKAN}

Adelaide, K. (2012). Gambaran Faktor-Faktor Penyebab Kecelakaan Lalu Lintas Di Jalan Tol Purbaleunyi Tahun 2010-2011. Tugas Akhir. Jakarta: Jurusan Teknik Sipil-Universitas Indonesia.

Kementerian Hukum dan Hak Asasi Manusia. (2004). Undang-Undang No. 38 Tahun 2004 Tentang Jalan. Jakarta: Sekretariat Negara Republik Indonesia.

Kementerian Hukum dan Hak Asasi Manusia. (2009). Undang-Undang Republik Indonesia Nomor 22 Tahun 2009 Tentang Lalu Lintas dan Angkutan Jalan. Jakarta: Sekretariat Negara Republik Indonesia.

Lestari, M. (2018), Kajian Mata Rantai Keselamatan Lalu Lintas di Jalan Tol Purbaleunyi. Tugas Akhir. Bandung: Jurusan Teknik Sipil-Institut Teknologi Nasional.

Perdana, S. N. (2018). Relavan Teori Perilaku Terencana Pada Niat Konsumen Pengguna Bus Trans Metro Bandung. Tugas Akhir. Bandung: Jurusan Teknik Sipil-Institut Teknologi Nasional.

PT Jasa Marga Cabang Purbaleunyi. (2018, Desember 3). PT Jasa Marga. Dipetik Desember 3, 2018, dari PT Jasa Marga Cabang Purbaleunyi: http://www.jasamarga.com/public/id/infolayanan/toll/ruas.aspx?title=Purwakarta\%20 -\%20Bandung\%20-\%20Cileunyi

Sugiyono. (2014). Metode Penelitian Kuantitatif, Kualitatif dan R\&D. Bandung: Alfabeta.

Tamin, O. Z. (2008). Perancangan dan Pemodelan Transportasi. Bandung: Institut Teknologi Bandung.

World Health Oganization. (2004). Kecelakaan Lalu Lintas. Dipetik April 14, 2019 dari https://id.wikipedia.org/wiki/Kecelakaan_lalu-lintas. 